\section{Association between a SLC6A3 intron 8 VNTR functional polymorphism and ADHD in a Brazilian sample of adult patients} Associação entre um polimorfismo VNTR funcional no intron 8 do gene SLC6A3 e TDAH em uma amostra de adultos brasileiros

\begin{tabular}{|c|c|c|c|c|}
\hline Genotypes & Cases (\%) & Controls (\%) & $x^{2}$ & p value \\
\hline $5 / 5$ & $5(5.32)$ & $38(7.90)$ & & \\
\hline $5 / 6$ & $32(34.05)$ & $230(47.82)$ & & \\
\hline $6 / 6$ & $54(57.45)$ & $203(42.20)$ & 8.49 & 0.038 \\
\hline Others & $3(3.18)$ & $10(2.08)$ & & \\
\hline Total & $94(100)$ & $481(100)$ & & \\
\hline \multicolumn{5}{|l|}{ Alleles } \\
\hline 5 & $43(22.87)$ & 307 (31.91) & 6.30 & 0.038 \\
\hline 6 & $142(75.53)$ & $645(67.05)$ & & \\
\hline Others & $3(1.60)$ & $10(1.04)$ & & \\
\hline Total & $188(100)$ & $962(100)$ & & \\
\hline
\end{tabular}

Allele $4=4$ repeat 30 base pair $(b p)$; allele $5=5$ repeat $30 \mathrm{bp}$; allele $6=6$ repeat $30 \mathrm{bp}$; allele $7=7$ repeat $30 \mathrm{bp}$; allele $10=10$ repeat $30 \mathrm{bp}$
Dear Editors,

Attention deficit hyperactivity disorder (ADHD) affects about 5\% of school-age children and from $1 \%$ to $6 \%$ of the adult population. ${ }^{1}$ It is highly heritable and familial influences seem strongest for ADHD persisting into adulthood. However, most of the genetic research in ADHD has been carried out in children and adolescents with the disorder.

Findings from pharmacological, neuroimaging and animal studies have suggested the involvement of specific neurotransmitter systems, notably the dopaminergic pathway. Among the dopaminergic genes, the one that has received most attention in ADHD genetics is the SLC6A3/DAT1 encoding the dopamine transporter, a transmembrane protein responsible for the presynaptic reuptake of dopamine. ${ }^{2}$ The $52.6 \mathrm{~kb}$ human SLC6A3 is located on chromosome 5 p.15.3. ${ }^{2}$

Persistance into adulthood may represent a promising marker for studying the genetic background of ADHD. As well, SLC6A3 is an important candidate gene for molecular association studies. Therefore, we have performed an investigation of a six-copy 30-bp variable-number tandem repeat (VNTR) functional polymorphism located in SLC6A3 intron $8^{3}$ in a Brazilian sample comprised by 94 adult patients with DSM-IV ADHD and 481 control subjects. Among the 94 ADHD patients, 58 (61.20\%) were males and 36 (38.30\%) were females, while in the control group, $323(67.15 \%)$ were males and 158 (32.85\%) were females. The mean ages of the ADHD and control groups were, respectively, $33.0(\mathrm{sd}=9.21$ ) and 32.5 ( $\mathrm{sd}=9.5$ ). More information about the clinical sample can be found elsewhere. ${ }^{4}$ The study was previously approved by the Clinical Hospital Ethics Committee and all participants gave their written informed consent.

The statistical power of the sample was evaluated using the CaTS Program (http://www.sph.umich.edu/csg/abecasis/CaTS/ index.html). Polymorphism frequency differences were investigated 
by the Monte Carlo method using the Clump v1.9 with 10,000 simulations. To perform such analysis, we have collapsed columns with small values into one group to maximize the chi-square value and produce more conservative results. The Hardy-Weinberg equilibrium was tested using the HWE Program.

The genotypic distribution was in Hardy-Weinberg equilibrium (cases: $\chi^{2}=1.15, p=0.99$ and controls: $\chi^{2}=8.65, p=0.76$ ). The power of the sample, based on 94 patients and 481 controls, a estimated disorder prevalence in adults of $2.0 \%$, average allelic frequency around 40\%, multiplicative model with the genotype relative risk $=1.6$, and significance level of 0.05 , was $86 \%$. The 6-repeat allele was statistically associated with ADHD $\left(\chi^{2}=6.30, p=0.038\right)$ - Table 1 . Although there was a rejection of the null hypothesis of homogeneity between the groups of cases and controls at the 0.05 level concerning the polymorphism distribution, the $p$-values (allelic and genotypic) were very close to the level set for significance (Table 1). Therefore, the difference between groups was small. In other samples the present results could be different.

A possible limitation of the present investigation may be related to population stratification. Researches investigating different ethnical populations have shown significant variations in the allelic frequency among them. However the fact that in the present study the patients and controls are in Hardy-Weinberg equilibrium must indicate that our sample may not have important problems of population stratification. ${ }^{5}$

The present study provides evidence for the association between the 6-repeat allele of the investigated polymorphism and ADHD in our Brazilian sample of adult patients. Recent investigation has also found in adults with ADHD the association replicated in the present study. ${ }^{2}$ Research on gene and environment interaction has evidenced that the 6-repeat allele of the 30-bp VNTR polymorphism may moderate the impact of the SLC6A3/DAT1 on ADHD symptoms, suggesting that DAT1 would affect only those individuals exposed to psychosocial adversity. ${ }^{6}$

A previous study that investigated the same polymorphism in a Brazilian sample compounded by children with ADHD observed no preferential transmission from parents to probands of any allele at the $3^{x}$ region of the gene, including the VNTR of intron $8 .^{7}$ If confirmed by longitudinal studies, this differential association of genes with $A D H D$, in children and in adults, might imply that SLC6A3 plays a role in modulating the ADHD phenotype, rather than causing the disorder. ${ }^{2}$

Maria Aparecida da Silva, Quirino Cordeiro, Mario Louzã, Homero Vallada Department and Institute of Psychiatry, Universidade de São Paulo (USP) Medical School, São Paulo (SP), Brazil

\section{Disclosures}

\begin{tabular}{|c|c|c|c|c|c|c|c|}
\hline $\begin{array}{l}\text { Writting group } \\
\text { member }\end{array}$ & Employment & $\begin{array}{l}\text { Research } \\
\text { grant }^{1}\end{array}$ & $\begin{array}{c}\text { Other research grant } \\
\text { or medical continuous } \\
\text { education }\end{array}$ & $\begin{array}{l}\text { Speaker's } \\
\text { honoraria }\end{array}$ & $\begin{array}{c}\text { Ownership } \\
\text { interest }\end{array}$ & $\begin{array}{l}\text { Consultant/ } \\
\text { Advisory } \\
\text { board }\end{array}$ & Other ${ }^{3}$ \\
\hline $\begin{array}{l}\text { Maria Aparecida da } \\
\text { Silva }\end{array}$ & Hospital M'Boi Mirim & - & - & - & - & - & - \\
\hline Quirino Cordeiro & $\begin{array}{l}\text { Hospital João } \\
\text { Evangelista }\end{array}$ & - & - & - & - & - & - \\
\hline Mario Louzã & IPq-HC-FMUSP & - & $\begin{array}{c}\text { Janssen Cilag } \\
\text { AstraZeneca } \\
\text { Elli Lilly } \\
\text { Novartis }\end{array}$ & $\begin{array}{c}\text { Janssen Cilag } \\
\text { AstraZeneca } \\
\text { Elli Lilly }\end{array}$ & - & $\begin{array}{c}\text { Janssen Cilag } \\
\text { AstraZeneca } \\
\text { Elli Lilly }\end{array}$ & - \\
\hline Homero Vallada & USP & - & - & - & - & - & - \\
\hline
\end{tabular}

${ }^{*}$ Modest

** Significant

*** Significant. Amounts given to the author's institution or to a colleague for research in which the author has participation, not directly to the author.

Note: IPq-FM-USP = Instituto de Psiquiatria do Hospital das Clínicas da Faculdade de Medicina da Universidade de São Paulo; USP = Universidade de São Paulo, $C N P q=$ Conselho Nacional de Desenvolvimento Cientifico e Tecnológico.

For more information, see Instructions for authors

\section{References}

1. Poeta LS, Rosa Neto F. Epidemiological study on symptoms of attention deficit/hyperactivity disorder and behavior disorders in public schools of Florianopolis/SC using the EDAH. Rev Bras Psiquiatr. 2004;26(3):150-5

2. Franke B, Hoogman M, Arias Vasquez A, Heister JG, Savelkoul PJ, Naber M, Scheffer H, Kiemeney LA, Kan CC, Kooiji JJ, Buitelaar JK. Association of the dopamine transporter (SLC6A3/DAT1) gene 9-6 haplotype with adult ADHD. Am J Med Genet B Neuropsychiatr Genet. 2008;147B(8):1576-9.

3. Guindalini C, Howard M, Haddley K, Laranjeira R, Collier D, Ammar N, Craig I, O'Gara C, Bubb VJ, Greenwood T, Kelsoe J, Asherson P, Murray RM, Castelo A, Quinn JP, Vallada H, Breen G. A dopamine transporter gene functional variant associated with cocaine abuse in a Brazilian sample. Proc Natl Acad Sci USA. 2006;103(12):4552-7.

4. da Silva MA, Louzã MR, Vallada HP. Attention deficit hyperactivity disorder (ADHD) in adults: social-demographic profile from a university hospital ADHD outpatient unit in São Paulo, Brazil. Arq Neuropsiquiatr. 2006;64(3A):563-7.
5. Cordeiro Q, Souza BR, Correa $H$, Guindalini C, Hutz MH, Vallada $H$, Romano-Silva MA. A review of psychiatric genetics research in the Brazilian population. Rev Bras Psiquiatr. 2009;31(2):154-62.

6. Laucht M, Skowronek MH, Becker K, Schmidt MH, Esser G, Schulze TG, Rietschel M. Interacting effects of the dopamine transporter gene and psychosocial adversity on attention-deficit/hyperactivity disorder symptoms among 15-year-olds from a high-risk community sample. Arch Gen Psychiatry. 2007;64(5):585-90.

7. Genro JP, Polanczyk GV, Zeni C, Oliveira AS, Roman T, Rohde LA, Hutz MH. A common haplotype at the dopamine transporter gene 5' region is associated with attention-deficit/hyperactivity disorder. Am J Med Genet B Neuropsychiatr Genet. 2008;147B(8):1568-75. 